\title{
Comparative Study on Performance of Tire Crumbles with Fly Ash and Kaolin Clay
}

\author{
Akash Priyadarshee ${ }^{1,2} \cdot$ Deepak Gupta $^{1} \cdot$ Vikas Kumar $^{1} \cdot$ Vaibhav Sharma $^{1}$
}

Received: 19 May 2015 / Accepted: 3 September 2015/Published online: 26 November 2015

(c) Springer International Publishing AG 2015

\begin{abstract}
In this study, the impact of tire crumbles as an admixture on compaction and strength behavior of two different materials, kaolin clay and fly ash is considered. In order to understand the compaction and strength behavior, proctor compaction tests and California bearing ratio (CBR) tests respectively were performed on the mixture of clay and fly ash with tire crumbles. Test results have shown that maximum dry unit weight decreases when tire crumbles are added in fly ash or clay. Increment in the optimum moisture content was also observed, when tire crumbles were added in clay. But no significant changes have been observed in case of fly ash. Test results have shown that the fly ash-tire crumble mix can sustain greater load than the clay-tire crumble mix. Improvement in CBR value is 5 times for clay and 3 times for fly ash with the addition of tire crumbles.
\end{abstract}

Keywords Tire crumbles - California bearing ratio . Kaolin clay $\cdot$ Fly ash

\footnotetext{
Akash Priyadarshee

i.akashpriyadarshee1@gmail.com

Deepak Gupta

deepakg757@gmail.com

Vikas Kumar

vikaskumarnitk@gmail.com

Vaibhav Sharma

civil.vaibhav.sharma@gmail.com

1 NIT Jalandhar, Jalandhar, India

2 Civil Engineering Department, NIT Jalandhar, Jalandhar, Punjab 144011, India
}

\section{Introduction}

To fulfill the needs of growing population, fast growth in the industrialization is taking place. The waste materials like fly ash, pond ash, tire waste etc. which are produced in huge amount are more challenging in terms of their utilization for different purposes. Such wastes can be used in bulk for various civil engineering projects. These wastes can be used as fill material or as admixtures for the improvement of the engineering properties of soil. Use of such materials as an admixture for improving the properties of soil is one of the important ground improvement techniques. Tire crumbles are one of the wastes which are produced due to the results of such industrialization. Improper dumping and huge amount of tire waste ignites many environmental problems. Utilization of such waste for different applications is the best way for the waste management. With increase in the amount of such wastes, it is becoming more difficult and expensive to dump such waste. Around 500 million tires stockpiled across the United States [1], 28 million across the Canada [2]. Use of tire waste as an admixture or as fill material for construction of geotechnical structure is one of the effective ways for the utilization of tire waste. In the construction of geotechnical structures like retaining wall, embankment etc. bulk utilization of tire waste is possible. Application of tire waste as light weight fill material is possible in road subgrade, embankment, retaining wall, slope stability etc. [3-5]. Tire wastes also have a potential to improve the engineering behavior of soil. It can be used for the improvement of load carrying capacity of weak soil when added as an admixture [6-8]. Many works are done on tire wastes, mixed with sand or clay, to understand the behavior of the mix and to identify the potential of tire waste in improving the engineering behavior of soil [6, 9-16]. 
Fly ash is another industrial waste produced during the burning of coal in the thermal power plant. Its production is also very huge, but utilization of is very less [17]. Disposal of fly ash is challenge for engineers, because of its adverse environmental impact [18, 19]. Fly ash can be used in bulk for geotechnical purposes [20]. The use of fly ash is becoming popular now-a-days. Researchers have shown that fly ash can be used in different structures like; in road and railway as subgrade [21-25], in construction of embankments of road and railways [26-29], in landfill liners [30], in waste stabilization [31] etc. Fly ash is basically a non plastic material. Studies have shown that use of such material can improve the behavior of fly ash [32-34].

Studies have shown that tire waste has significant potential to improve the strength of clay as well as granular soil. But the difference in the performance of tire crumbles in some plastic and non-plastic material is not yet well understood. In this paper, a comparative study has been conducted to understand the effect of tire waste inclusion on the clay and fly ash which are plastic and non-plastic materials respectively. Two properties, strength and compaction are considered to understand the performance of tire waste.

\section{Test Materials}

\section{Soil}

Soil used in this study was kaolin clay. Before carrying out strength and compaction tests, the soil was air dried, and then basic tests were performed. Particle size distribution was obtained by performing wet sieve analysis and hydrometer analysis. The grain size distribution of clay is shown in Fig. 1. The specific gravity of clay was found to be 2.66. Values of liquid limit; plastic limit and plasticity index were found 41.2, 21.1 and $20.1 \%$ respectively. Thus the soil is classified as CL (clay with low plasticity) according to unified soil classification system (USCS).

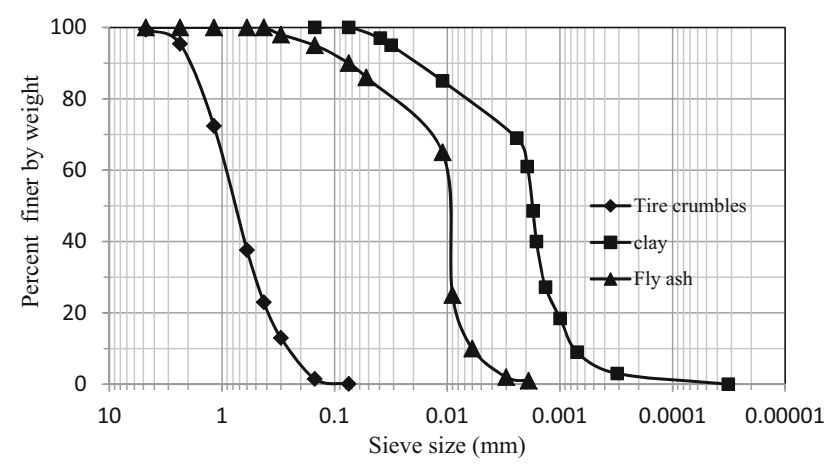

Fig. 1 Particle size distribution of clay, fly ash and tire crumbles

\section{Tire Crumbles}

Tire wastes used in this study were in form of crumbles (Fig. 2a), which is referred to as tire crumbles. Tire crumbles are the dust or powdered waste material, produced during the process of retreading of tire. Tire crumbles used in this study were taken from Speed Ways Tire Retreading Unit, Jalandhar, Punjab, India. The properties of tire crumbles used are presented in Table 1. Distribution of the sizes of crumble tires is presented in Fig. 1. It can be observed that the size of tire crumbles shows proper size grading as that of sand or clay. The gradation of tire crumbles is equivalent to the poorly graded sand (SP) according to the USCS classification.

\section{Fly Ash}

Fly ash was collected from Ropar thermal power plant, Ropar, Punjab, India. Grain size distribution of fly ash is depicted in Fig. 1. It can be observed that the most of the particles of fly ash lies in silt size. As per USCS classification system it can be classified as ML. The basic physical and index properties of fly ash are presented in Table 2. As per ASTM standard fly ash is classified as F-Class fly ash.

\section{Experimental Detail}

In this study, compaction and strength behavior of both fly ash and clay when mixed with tire crumbles are evaluated and compared. A series of standard compaction test, modified compaction test and CBR tests on the mix of tire crumbles-fly ash and tire crumbles-clay were performed. Three different series of tests 1, 2 and 3 were performed. Tests in series 1 were performed on the pure clay and fly ash with no tire crumbels. Test series 2 was performed on the Clay mixed with tire crumbles and test series 3 was performed on fly ash mixed with tire crumbles. On each series of tests, both compaction and CBR tests were performed. The content of the tire crumbles (TC) was varied as $1,2,5,10$ and $20 \%$ by weight. Such high range of tire crumbles content is used to fulfill two purposes first the maximum utilization of the tire wastes and determination of the content at which maximum performance of the tire reinforcement can be achieved.

To evaluate the compaction behavior, proctor tests and for strength behavior, CBR tests were conducted. Standard proctor tests and modified proctor tests were conducted on different proportion of soil mixtures. In proctor tests, mix of soil-admixtures was prepared by replacing soil by admixtures. All CBR tests were conducted on the soil-admixtures mix prepared at maximum dry unit weight and optimum moisture content (OMC) obtained from modified 


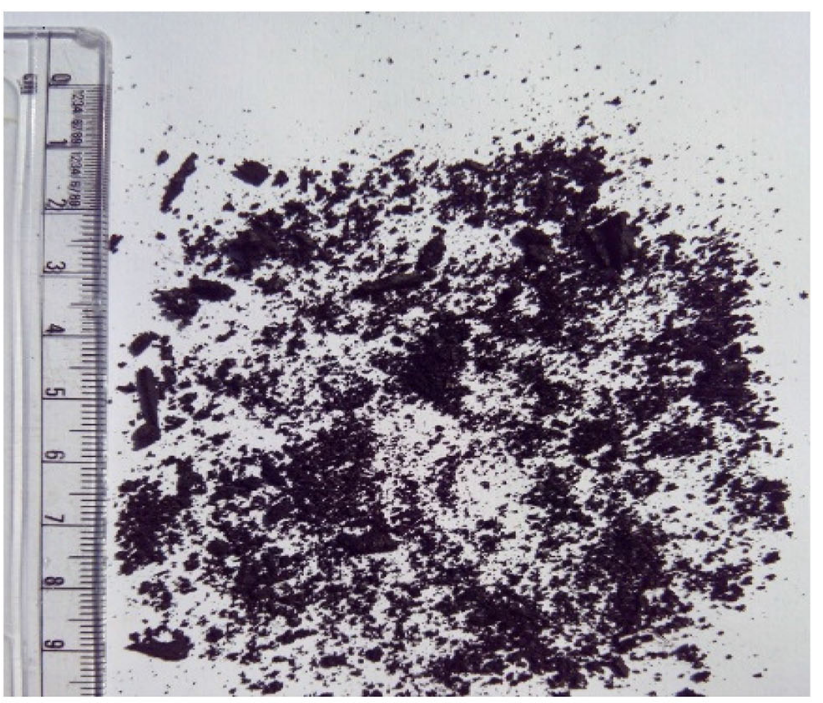

(a)

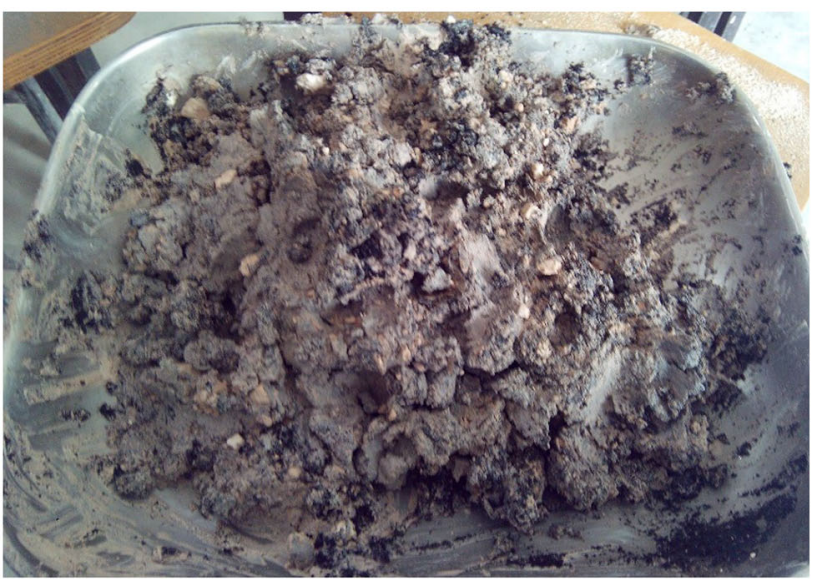

(b)

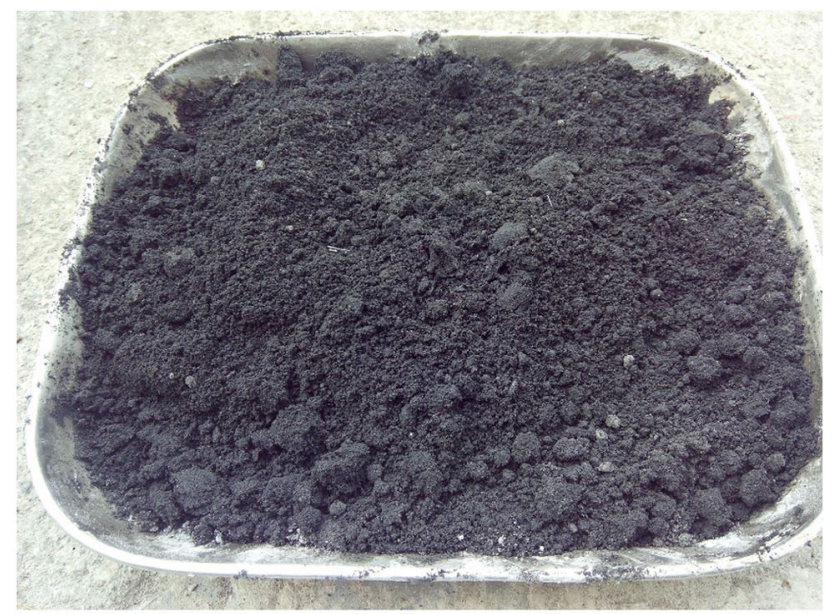

(c)

Fig. 2 Photographic view of tire crumbles and mixture of tire crumbles with clay and fly ash used in this study. a Tire crumbles, b clay mixed with tire crumbles, $\mathbf{c}$ fly ash mixed with tire crumbles
Table 1 Properties of tire crumbles

\begin{tabular}{ll}
\hline Properties & Values \\
\hline Specific gravity $(G)$ & 1.01 \\
$D_{60}(\mathrm{~mm})$ & 0.92 \\
$D_{50}(\mathrm{~mm})$ & 0.73 \\
$D_{30}(\mathrm{~mm})$ & 0.52 \\
$D_{10}(\mathrm{~mm})$ & 0.26 \\
Coefficient of uniformity $\left(C_{\mathrm{u}}\right)$ & 3.54 \\
Coefficient of curvature $\left(C_{\mathrm{c}}\right)$ & 1.13 \\
\hline
\end{tabular}

Table 2 Properties of the fly ash

\begin{tabular}{ll}
\hline Properties & Value \\
\hline Color & Blackish green \\
Shape & Rounded \\
Specific gravity $(G)$ & 2.10 \\
$D_{50}(\mathrm{~mm})$ & 0.01 \\
$C_{\mathrm{u}}$ & 1.84 \\
$C_{\mathrm{c}}$ & 1.37 \\
Plasticity index & Non-plastic \\
\hline
\end{tabular}

compaction test. All CBR tests were conducted on unsoaked condition. All the tests were conducted as per the relevant ASTM standards.

Soil mixtures were prepared by the manual mixing. First, required weight of soil and admixtures were taken and mixed by hand uniformly. After mixing of soil and admixtures, required amount of water was added and mixed uniformly. The contents of constituents of mix are taken as percent of total weight of the mixture. Content (TC) of the constituent present in the mix can be defined as the ratio of the weight of constituent to the total weight of the mix. The general expression for the total weight of the Fly ash- tire crumbles $\left(W_{\mathrm{FT}}\right)$ and clay-tire crumbles $\left(W_{\mathrm{CT}}\right)$ can be expressed as

$W_{\mathrm{FT}}=W_{\mathrm{F}}+W_{\mathrm{T}}$

$W_{\mathrm{CT}}=W_{\mathrm{C}}+W_{\mathrm{T}}$

where $W_{\mathrm{C}}, W_{\mathrm{F}}$, and $W_{\mathrm{T}}=$ weight of clay, weight of fly ash, and weight of tire crumbles respectively. Photographs of mixture of clay and fly ash with tire crumbles are presented in Fig. 2b, c.

\section{Results and Discussion}

Test results obtained from the modified compaction tests and CBR tests on fly ash and clay are presented in following sections and discussed to evaluate the compaction and strength behavior respectively. 


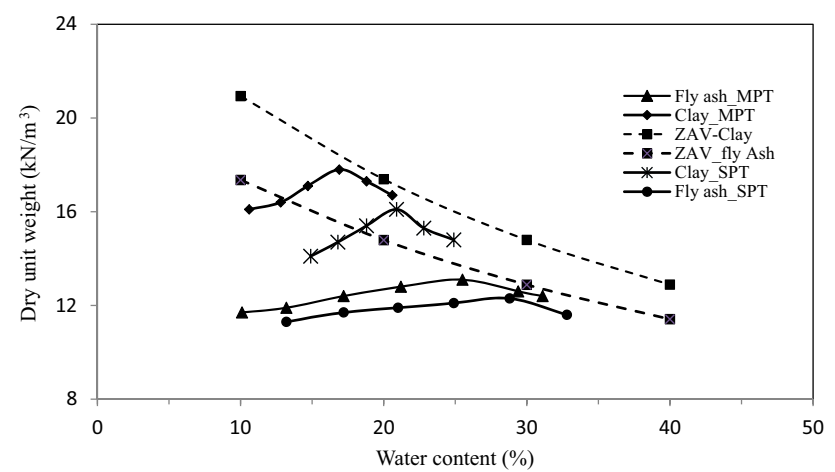

Fig. 3 Compaction behavior of clay and fly ash

\section{Compaction Behavior}

Compaction behavior of the kaolin clay and fly ash obtained from the standard proctor test (SPT) and modified proctor tests (MPT) are presented in Fig. 3. Zero-air void lines corresponding to the fly ash and clay are also presented. It can be observed that the maximum dry unit weight of clay is higher than that of fly ash. This is because of the higher specific gravity of clay. The compaction curves show that the effect of the variation of moisture content on the dry unit weight of soil is less for fly ash than for clay. It shows that fly ash is less sensitive to moisture content. This is attributed to the higher air void content in fly ash than clay [20]. It can further be noted that in case of fly ash, maximum dry unit weight increases from 12.3 to $13.1 \mathrm{kN} / \mathrm{m}^{3}$, while in case of clay; it is increasing from 16.1 to $17.8 \mathrm{kN} / \mathrm{m}^{3}$. It shows that the effect of the compaction effort on the clay is greater than fly ash. Compaction curves of tire crumbles are depicted in Fig. 4. Tire crumbles are showing decreasing trend in the dry unit weight, when amount of water was less than $10 \%$. After that further improvement in the dry unit weight was observed and it reaches to maximum dry unit weight. The decrease in the density of the tire crumbles is due the 'bulking' phenomena. With the increase in compaction effort, increase in the maximum dry unit weight is taking place, but no significant change in the optimum moisture content is found.

The compaction behavior of clay-tire crumbles mix obtained from the test results of MPT is presented in Fig. 5. Here, the compaction curve is shifting right ward and downward with increment in the tire content. It indicates that the maximum dry unit weight is decreasing and optimum moisture content is increasing. Lower value of specific gravity of tire crumbles (Table 2) is the reason for the reduction of maximum dry unit weight. Since the more water is required to compact the tire crumbles than clay, so, optimum moisture content is increasing with increase in the tire crumbles. Ozkul and Bayal [7] and Cetin et al. [6] have also reported the similar compaction behavior when

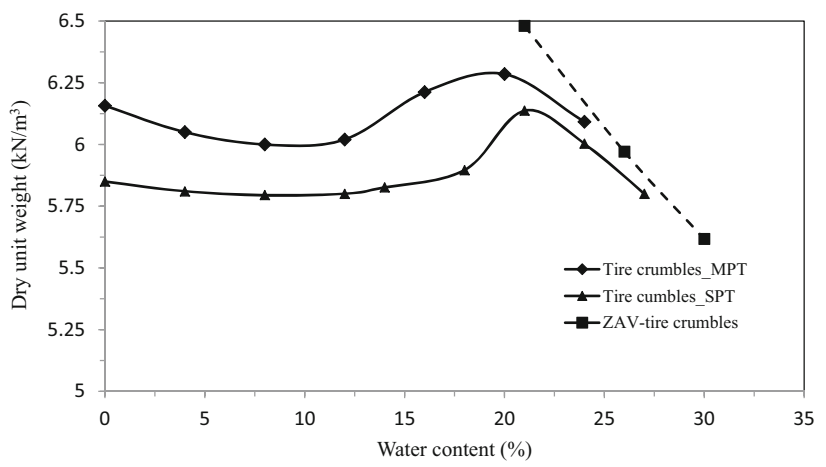

Fig. 4 Compaction behavior of tire crumbles

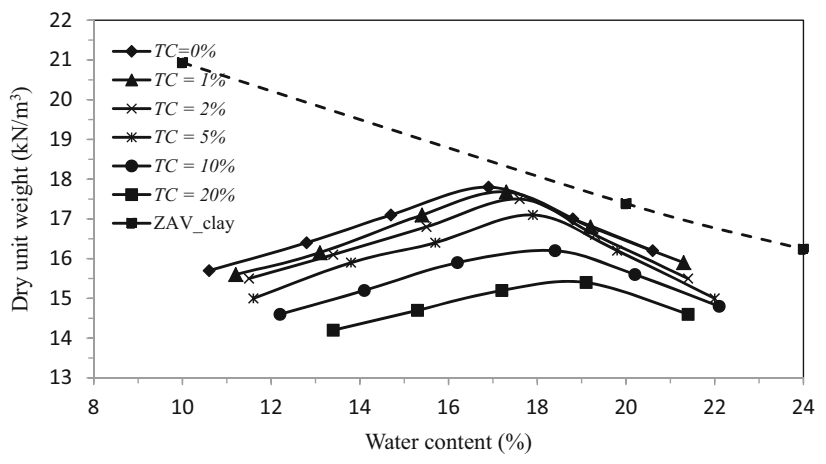

Fig. 5 Compaction behavior of clay-tire crumbles mix (MPT)

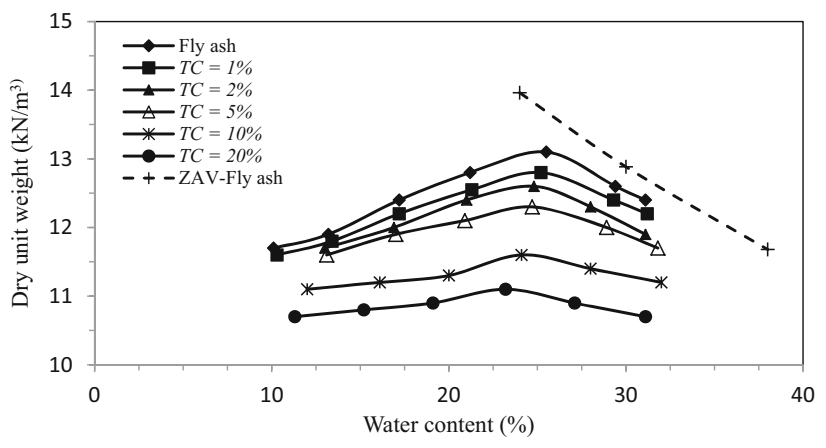

Fig. 6 Compaction behavior of fly ash-tire crumbles mix (MPT)

Kaolinite clay was mixed with tire buffing. Figure 6 represents the compaction behavior of fly ash mixed with tire crumbles. It also shows that with increase in the amount of tire crumbles decrease in the maximum dry unit weight takes place. In this case also, reduction is taking place because of the lower specific gravity of the tire crumbles. There is no significant effect by the tire crumbles inclusion on the optimum moisture content of the mix. Less amount of water is required for compaction of tire crumbles than fly ash (Figs. 4 vs. 6). So there is slight decrease in the optimum moisture content due to addition of the tire crumbles in fly ash (Fig. 6). 


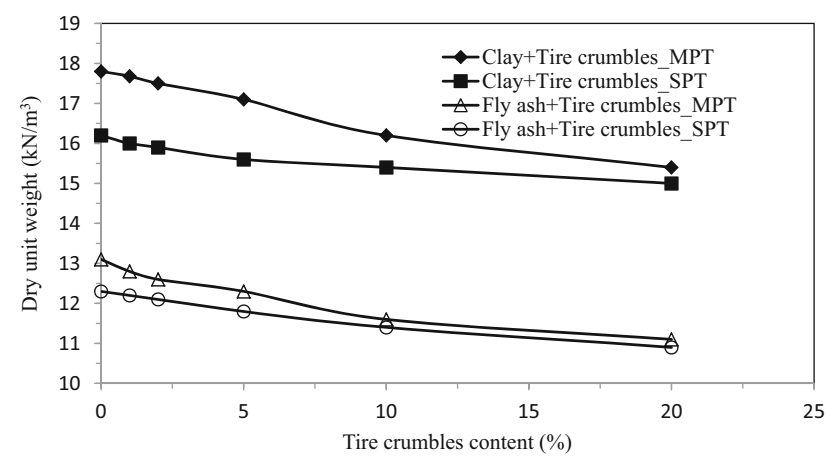

Fig. 7 Effect of compaction effort on clay and fly ash mixed with tire crumbles

The effect of tire crumbles on the compaction behavior of fly ash and clay is depicted in Fig. 7. The effect of the compactive effort on maximum dry unit weight is also presented in Fig. 7. It can be observed that with increase in the compactive effort, maximum dry unit weight is increasing. For fly ash and clay, both the difference in the maximum dry unit weight at lower compaction effort (SPT) and higher compaction effort (MPT) is greater when tire crumbles content is less. But at higher tire crumbles content, the difference in the maximum dry unit weight is marginal. It shows that the tire crumbles suppress the effect of compactive effort. The flexible nature of the tire crumble is the possible reason for such behavior. Fly ash-tire crumbles mix are relatively lighter than the clay-tire crumbles mix. Such lighter mix is very effective for the structures like retaining walls, where light fill materials are beneficial for stability of the structure.

\section{Strength Behavior}

Stress-penetration behavior of the clay-tire crumble mix is depicted in Fig. 8. It can be observed that the load carrying capacity of clay is increasing with the increase in tire crumble content. The load carrying capacity of clay is mainly because of the cohesion, since it is plastic material. Due to the inclusion of tire crumble, interaction between the tire crumble and clay increases the frictional component of the mix. This interaction increases the overall load carrying capacity of the mix. But up to a certain limit of tire crumbles content i.e. $5 \%$, the improvement in the load carrying capacity is marginal. This value of tire crumbles content is known as optimum content of tire for strength improvement. At higher content, the interaction between clay and tire crumbles decreases due to the more availability of the tire crumble, so, further improvement in the load carrying capacity doesn't take place. Singh and Vinot [35] have also reported the optimum content of tire with clay around $5 \%$ for significant improvement in the load carrying capacity of

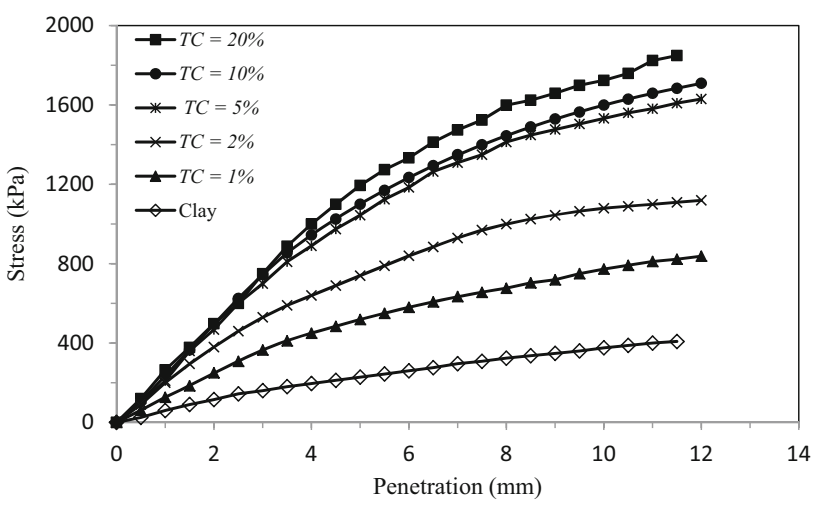

Fig. 8 Stress-penetration behavior of clay-tire crumbles mix

tire mixed with clay. If carefully observed, stress-penetration curves at lower content of the tire crumbles is tending to nearly asymptotic state. While at higher content of tire crumbles, stress-penetration curve is relatively ascending in nature. Tire crumbles are flexible in nature, so, at higher content, the overall mix became flexible i.e. the ductility of the mix increases. Due to this, the load-penetration behavior shows the ascending trend. The slope of the stress-penetration curve, which is the representation of the stiffness of the mix, is also increasing with increase in the content of tire crumble. But at higher content, when flexibility of the mix is higher, improvement in the stiffness of the mix was not significant. Similar type of behavior of load-penetration curve is found for the fly ash-tire crumble mixture (Fig. 9). Load carrying capacity and stiffness, both increases with increase in the tire crumble content up to the optimum content of tire i.e. $5 \%$. Marginal improvement in the load carrying capacity is found after this optimum limit of tire crumbles content. Since, the fly ash is a non plastic material; the resistance against penetration is mainly contributed by the frictional component. Tire crumble inclusion increases the frictional resistance through the interaction between fly ash and tire crumbles. So, due to this, the resistance against penetration increases upto $5 \%$ of tire crumbles content. But at higher content of tire, interaction within tire crumbles increases and interaction between soil and tire crumbles decreases. Due to this reason, beyond $5 \%$ of tire crumbles content improvement in load carrying capacity is marginal. In case of fly ash at tire crumbles content of $20 \%$, decrease in the load carrying capacity can be observed. Reduction in the interaction between fly ash-tire crumble mix is more than the clay-tire crumble mix (Figs. 8, 9). It is because; the size of the particles of the fly ash is greater than that of clay (Fig. 1). Consequently, less number of particles of fly ash will be available for the interaction with the tire crumbles at higher content. Researchers like Foose et al. [11], Masad et al. [12] Youwai and Bergado [15] etc. have also shown that shearing resistance against the deformation increases due to interaction between sand and tire wastes. 


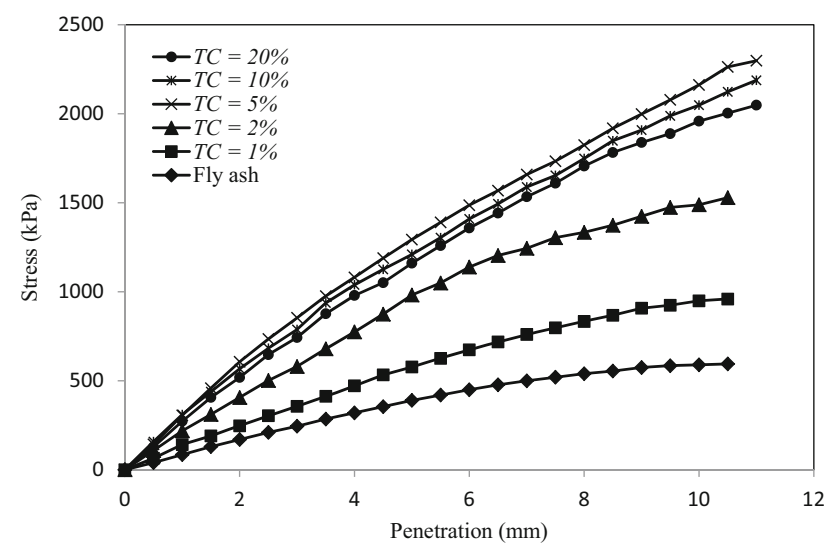

Fig. 9 Stress-penetration behavior of fly ash-tire crumbles mix

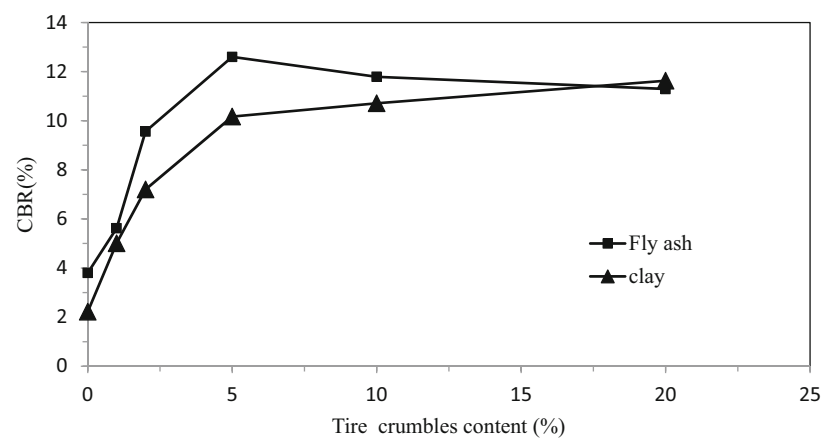

Fig. 10 Variation of California bearing ratio with tire crumbles content

Variation of the California bearing ratio (CBR) with tire crumbles content for fly ash and clay is presented in the Fig. 10. CBR values of the fly ash-tire crumble mixes are greater as compared to the clay-tire crumble mix. It indicates that the mix of fly ash and tire crumbles can sustain greater load. After an optimum value of the tire crumbles content ( $\mathrm{TC}=5 \%$ ), the value of CBR is decreasing for the fly ashtire crumble mix, but for clay-tire crumbles mix marginal improvement in the CBR is taking place. It indicates that at lower content of tire, fly ash-tire crumble mix can perform better, while at higher content of tire crumble, its performance is equivalent to the clay-tire crumble mix. It can be further noted that the improvement in the CBR value in case of fly ash is more when tire crumbles content is between 1 and $2 \%$ than $0-1 \%$. The possible reason might be the better gradation, when the tire crumbles content is between 1 and $2 \%$. The term improvement factor $\left(I_{\mathrm{f}}\right)$ have been introduced to check the improvement in CBR value of any mix with respect to CBR value of pure clay or fly ash. The expression for $I_{\mathrm{f}}$ can be written as follows.

$I_{\mathrm{f}}=\frac{\mathrm{CBR} \text { of mix }}{\text { CBR of pure clay or fly ash }}$

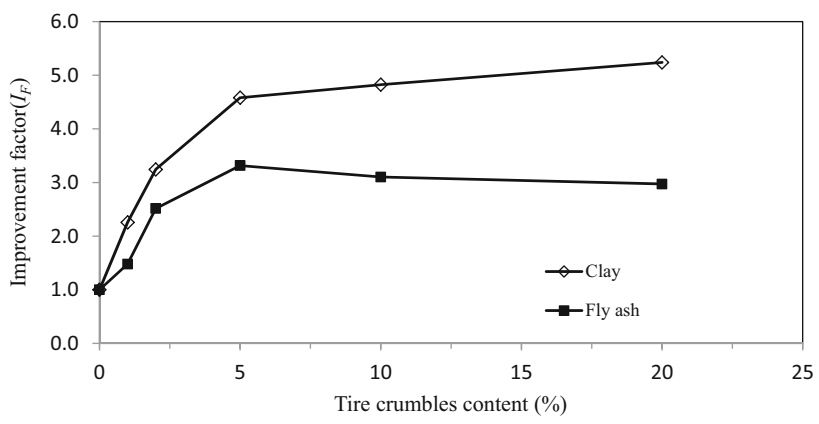

Fig. 11 Variations of improvement factor with tire crumble content

Figure 11 shows the variation of $I_{\mathrm{f}}$ with tire crumble content for fly ash and clay. $I_{\mathrm{f}}$ is the ratio of the CBR of mix of fly ash or clay with tire crumble to the CBR of the pure clay or fly ash.

The $I_{\mathrm{f}}$ is also supporting the fact that after an optimum value of tire crumbles content the improvement is not significant. But it can be observed that the performance of tire crumbles in terms of $I_{\mathrm{f}}$ is better in case of clay.

\section{Conclusions}

In present study, the proctor tests and California bearing ratio tests were performed to understand the performance of the tire crumbles in two different materials; clay, which is plastic material and fly ash, which is non-plastic in nature. The major conclusions drawn from this study is presented as follows:

- Maximum dry unit weight decreases due to the inclusion of tire crumbles. But, the fly ash-tire crumbles mix are lighter than the clay-tire crumble mix. So the structure where light fill material is required, mix of fly ash-tire crumbles should be preferred.

- The effect of compactive effort is not significant for the mix with higher amount of tire content, because of the flexible nature of the tire crumbles.

- Tire crumbles can effectively increase the strength and stiffness of fly ash and clay. Load-penetration behavior of mixes has shown that the ductility of the mix increases with the inclusion of tire crumbles.

- CBR value of the mix increases with increase in the content of tire crumbles up to a certain limit of tire crumbles content $(\mathrm{TC}=5 \%)$ known as optimum content, after which, further improvement in the CBR is not significant. CBR of fly ash-tire crumble mixes are greater as compared to clay-tire crumble mix.

- Improvement factor $\left(I_{\mathrm{f}}\right)$ is found better in case of clay, due to the inclusion of tire crumbles, than fly ash. Reduction in the improvement factor takes place after 
optimum content of tire crumble for fly ash and marginal increase takes place in case of clay.

\section{References}

1. Edincliler A, Baykal G, Saygili A (2010) Influence of different processing techniques on the mechanical properties of used tire in embankment construction. Waste Manag 30:1073-1080

2. Dickson TH, Dwyer DF, Humphrey DN (2001) Prototypes tireshred embankment construction. Transportation Research Record 1755, TRB, National Research Council, Washington, DC, pp $160-167$

3. Eldin NN, Senouci AB (1992) Use of scrap tires in road construction. J Constr Eng Manag 118(3):561-576

4. Bosscher PJ, Edil TB, Kuraoka S (1997) Design of highway embankments using tire chips. J Geotech Geoenviron Eng 123(4):295-304

5. Eid HT, Stark TD, Evans WD, Sherry PE (2000) Municipal solid waste slope failure I: waste and foundation soil properties. J Geotech Geoenviron Eng 126(5):397-407

6. Cetin H, Fener M, Gunaydin O (2006) Geotechnical properties of tire-cohesive clayey soil mixtures as a fill material. Eng Geol 88:110-120

7. Ozkul ZH, Baykal G (2006) Shear strength of clay with rubber fiber inclusion. Geosynth Int 13(5):173-180

8. Akbulut S, Arasan S, Kalkan E (2007) Modification of clayey soils using scrap tire rubber and synthetic fibers. Appl Clay Sci 38:23-32

9. Ahmmed I (1993) Laboratory study on properties of rubber-soil. Joint Highwaty Research Project. Report No. FHWA/IN/JHRP93/4. Indiana Department of Transportation-Dep. of Civil Engineering, Purdue University, West Lafayetter, Ind. Indiana, p 384

10. Edil T, Bosscher P (1994) Engineering properties of tire-chips and soil mixtures. Geotech Test J 17:453-464

11. Foose G, Benson C, Bosscher P (1996) Sand reinforced with shredded waste tires. J Geotech Geoenviron Eng 122:760-767

12. Masad E, Taha R, Ho C, Papaginanakis T (1996) Engineering properties of tire/soil mixtures as lightweight fill. Geotech Test J 19:297-304

13. Wu WY, Benda CC, Cauley RF (1997) Triaxial determination of shear strength of tire chips. J Geotech Geoenviron Eng 123:479-482

14. Yang S, Lohnes RA, Kjartanson BH (2002) Mechanical properties of shredded tires. Geotech Test J 25:44-52

15. Youwai S, Bergado DT (2003) Strength and deformation characteristics of shredded rubber tire-sand mixtures. J Can Geotech 40:254-264

16. Rao GV, Dutta RK (2006) compressibility and strength behavior of sand tire chip mixtures. Geotech Geol Eng 24(3):711-724
17. Pandian NS, Krishna KC (2003) The pozzolanic effect of fly ash on the California Bearing Ratio of black cotton soil. J Test Eval 31(6): $1-7$

18. Martin JP, Collins RA, Browning JS, Biehl FJ (1990) Properties and use of fly ashes for embankments. J Energy Eng 116(2):71-86

19. Misra A, Biswas D, Upadhyaya S (2005) Physico-mechanical behavior of self cementing class $\mathrm{C}$ fly ash-clay mixture. Fuel 84:1410-1422

20. Pandian NS (2004) Fly ash characterization with reference to geotechnical applications. J Indian Inst Sci 84:189-216

21. Raymond S (1958) Utilization of pulverized fuel ash. Civ Eng Public Works Rev (Lond) 53:1013-1016

22. Digioia AM, Nuzz WL (1972) Fly ash as structural fill. J Power Div 98(1):77-92

23. Winterkorn HT (1975) Soil stabilization. In: Winterkorn HF, Fang FY (eds) Foundation engineering handbook. Van Nostrand Reinhold, New York

24. Tooth PS, Chan HT, Cragg CB (1988) Coal ash as structure fills, with special reference to Ontario experience. Can Geotech J 25:694-704

25. Glogowski PE, Kelly JM, Mclaren RJ, Burns DL (1972) Fly ash design manual for road and site applications. Rep. RP2422-2, prepared for Electric Power Research Institute, GAI Consultants, Pittsburgh

26. Gray DH, Lin YK (1972) Engineering properties of compacted fly ash. J Soil Mech Found Div 98(4):361-380

27. Huang WH (1990) The use of bottom ash in highway subgrade and subbases. Joint Highway Research Project, Final Rep. HWA/ IN/JHRP-90/4. Purdue University, West Lafayette

28. Huang WH, Lovell CW (1990) Bottom ash as embankment material. In: Landva A, Knowles GD (eds) Geotechnics of waste fills-theory and practice. ASTM Special Technical Publication 1070. ASTM, West Conshohocken

29. Rai AK, Paul B, Singh G (2006) A study on backfill properties and use of fly ash for highway embankments. J Adv Lab Res Biol 1(2):110-114

30. Bowders JJ Jr., Uamen MA, Gidley JS (1987) Stablized fly ash for use as low permeability barriers. Geotechnical practice for waste disposal 87: geotechnical special publication no. 13. R.D. Woods, Oak Creek, pp 320-447

31. Martin JP, Flesper AJ, Van Keuren EL (1987) Hydrocarbon refining waste stabilization for landfills. Geotechnical practice for waste disposal 87: geotechnical special publication no. 13. R.D. Woods, Oak Creek, pp 668-682

32. Hazra S, Patra NR (2008) Performance of counterfort walls with reinforced granular and fly ash backfill-experimental investigation. Geotech Geol Eng 26:259-267

33. Lal BRR, Mandal JN (2012) Feasibility study on fly ash as backfill material in cellular reinforced wall. EJGE 17:1437-1458

34. Cokca E, Yilmaz Z (2004) Use of rubber and bentonite added fly ash as a liner material. Waste Manag 24:153-164

35. Singh B, Vinot V (2011) Influence of waste tire chips on strength characteristics of soils. J Civ Eng Archit 5(9):819-827 